Received 07.05.2016 Reviewed 28.06.2016 Accepted 04.07.2016

A - study design

B - data collection

C - statistical analysis

D - data interpretation

$\mathbf{E}$ - manuscript preparation

F - literature search

\section{Agro-climatic zoning in Egypt to improve irrigation water management}

\author{
Tahany NORELDIN ${ }^{1) \text { BCE }}$, Samiha OUDA ${ }^{\text {1) ADF }}$, Alia AMER ${ }^{\text {2) BCE }}$
}

\footnotetext{
${ }^{1)}$ Water Requirement and Field Irrigation Department; Soils, Water and Environment Research Institute; Agricultural Research Centre, Egypt; e-mail: dr.tahany2013@gmail.com, samihaouda@yahoo.com

${ }^{2)}$ Medicinal and Aromatic Plant Research Department; Horticulture Research Institute; Agricultural Research Centre; e-mail: dr_aliaamer@yahoo.com
}

For citation: Noreldin T., Ouda S., Amer A. 2016. Agro-climatic zoning in Egypt to improve irrigation water management. Journal of Water and Land Development. No. 31 p. 113-117. DOI: 10.1515/jwld-2016-0041.

\begin{abstract}
The objective of this paper was to develop agro-climatic zones in the old cultivated lands of Egypt in the Nile Delta and Valley using climate normals from 1985-2014 to facilitate better irrigation water management under water scarcity conditions. 30-yearmonthly climate data were collected for 17 agricultural governorates in Egypt and yearly averages and 30-year averages were calculated. BISm model was used to calculate yearly averages of potential evapotranspiration $(P E T)$ and 30-year average for each governorate. Analysis of variance was done using one factor randomize complete block design, with number of years as replicates. Furthermore, the mean, the range and $R^{2}$ were calculated to test the strength of the relationship between PET and climate elements. The means of $P E T$ for each governorate was separated and ranked in ascending order using least significant difference test $\left(L S D_{0.05}\right)$. The results identified 7 agro-climatic zones $\left(L S D_{0.05}=0.146\right)$. These zones were: (1) Alexandria; (2) Demiatte, Kafr El-Sheikh and Dakhlia; (3) El-Behira, and El-Gharbia; (4) El-Minofia, El-Sharkia, El-Kalubia, Giza and El-Fayom; (5) Beni Sweif, El-Minia, Assuit and Sohag; (6) Qena; and (7) Aswan. Such zoning will increase the ability of the Egyptian policy makers to prepare the appropriate water management and development policies as a result of the availability of proper information on each zone aiming at efficient use of the limited water resources.
\end{abstract}

Key words: 30-year climate data, efficient water use, governorates, Penman-Monteith equation, potential evapotranspiration

\section{INTRODUCTION}

Egypt is one of these areas that already experiencing water scarcity, although it is gifted by the Nile River, which is the main water source for irrigation and other uses. Egypt has reached a state, where the quantity of water available is imposing limits on its national economic development [ABOU ZEID 2002]. This situation creates challenges for agricultural scientists to manage the available water resources properly, taking into consideration water resources conservation. One of the suggestions to attain that is to implement agro-climatic zoning. A particular region can be divided into agro-climatic zones based on homogeneity in weather variables that have the greatest influence on crop growth and yield [DOORENBOS, KASSAM 1979]. Thus, agro-climatic zone is a land unit in terms of major climate, superimposed on length of growing period i.e. moisture availability period [FAO 1983]. As a result, crops growth periods, water requirements and irrigation scheduling are dependent on weather conditions. Potential evapotranspiration $(P E T)$ is the major determinant of crops water requirements. It is a combination of two processes water evaporation from soil surface and transpiration from the growing plants GARDNER et al. [1985]. Di- 
rect solar radiation and, to a lesser extent, the ambient temperature of the air provides energy for evaporation. Whereas, solar radiation, air temperature, air humidity and wind speed should be considered when assessing transpiration [ALLEN et al. 1989]. Various equations varying in the degree of complexity are available for estimating PET. However, the PenmanMonteith equation is widely recommended, although it is characterized by its complication, its detailed theoretical base and its accommodation of small time periods overcomes its complexity.

There were several attempts in Egypt to develop agro-climatic zones. The earliest one was the division of Egypt into three main agro-climatic zones, i.e.

\section{MATERIALS AND METHODS}

\section{THE SELECTED SITES}

The Nile Delta and Valley is composed of 17 governorates and it is called the old cultivated. The soil of these governorates is mainly clay (heavy soils). The very common classification of Egypt's agricultural governorates is Nile Delta (9 governorates), Middle Egypt (4 governorates) and South Egypt (4 governorates). Such governorates are shown in Figure 1 and the latitude, longitude and elevation above sea level are shown in Table 1.

Lower Egypt, Middle Egypt and Upper Egypt, which was more administrative than climatic [EL-BAGOURI 2008]. Further zoning for Egypt divided the country into 9 agro-zones: (1) Coastal zone; (2) Central Delta; (3) East and West Delta; (4) Giza; (5) Minia; (6) Assuit and Sohag; (7) North Qena; (8) South Qena and (9) Aswan [EID et al. 2006]. The previous classification depended on the calculation of annual PET for each governorate. When the difference between the PET of several governorates was less than $5 \%$, they grouped together in one zone EID et al. [2006]. MEDANY [2007] developed agro-ecological zones using regression equations to predict reference evapotranspiration for a certain zone using average temperature and month number in the year. These zones were: (1) North Delta (Dakhlia, Gharbia, Damietta and Kafr El-Sheikh); (2) West Delta (Alexandria and Behira governorates); (3) Middle Delta, (Ismailia, Kalubia, Minofia, Port-Said, Sharkia governorates); (4) South Delta (Gi-

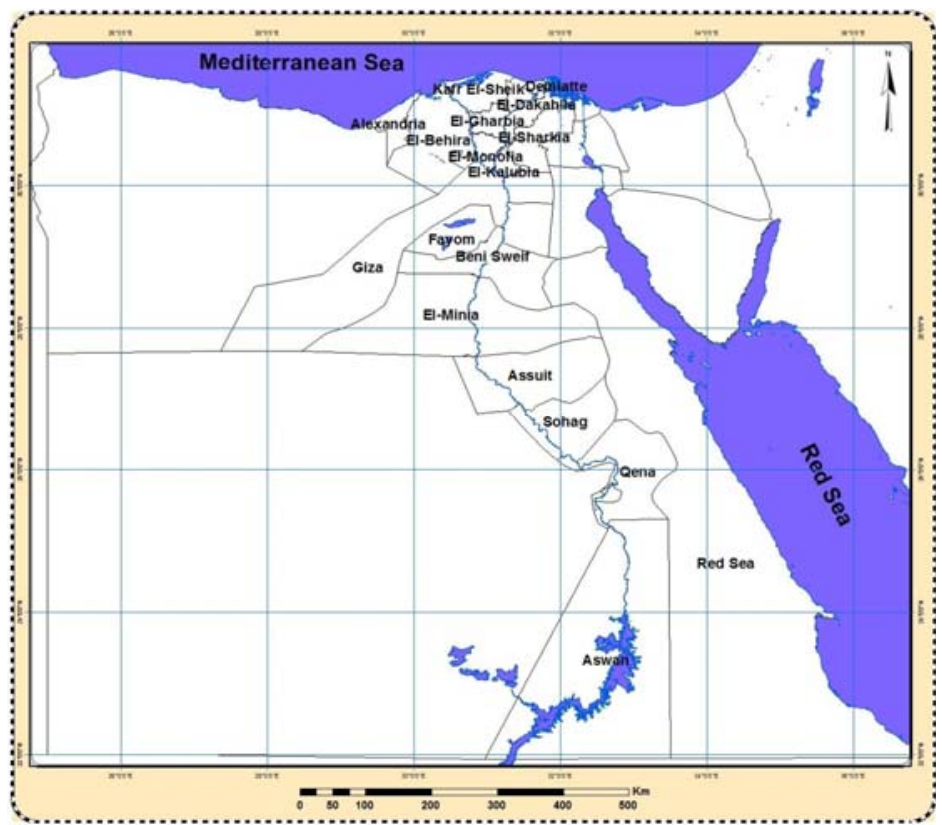

Fig. 1. Studied governorates in the Nile Delta and Valley, Egypt; source: own elaboration

Table 1. Latitude, longitude and elevation above sea level for the studied governorates in the Nile Delta and Valley

\begin{tabular}{|c|c|c|c|}
\hline Governorate & Latitude & Longitude & $\begin{array}{c}\text { Elevation } \\
\text { m a.s.l. }\end{array}$ \\
\hline \multicolumn{4}{|c|}{ Nile Delta } \\
\hline Alexandria & $31.70^{\circ}$ & $29.00^{\circ}$ & 7.00 \\
\hline Damietta & $31.25^{\circ}$ & $31.49^{\circ}$ & 5.00 \\
\hline Kafr El-Sheik & $31.07^{\circ}$ & $30.57^{\circ}$ & 20.00 \\
\hline El-Dakahlia & $31.03^{\circ}$ & $31.23^{\circ}$ & 7.00 \\
\hline El-Behira & $31.02^{\circ}$ & $30.28^{\circ}$ & 6.70 \\
\hline El-Gharbia & $30.47^{\circ}$ & $32.14^{\circ}$ & 14.80 \\
\hline El-Minofia & $30.36^{\circ}$ & $31.01^{\circ}$ & 17.90 \\
\hline El-Sharkia & $30.35^{\circ}$ & $31.30^{\circ}$ & 13.00 \\
\hline El-Kalubia & $30.28^{\circ}$ & $31.11^{\circ}$ & 14.00 \\
\hline \multicolumn{4}{|c|}{ Middle Egypt } \\
\hline El-Giza & $30.02^{\circ}$ & $31.13^{\circ}$ & 22.50 \\
\hline El-Fayom & $29.18^{\circ}$ & $30.51^{\circ}$ & 30.00 \\
\hline Beni Sweif & $29.04^{\circ}$ & $31.06^{\circ}$ & 30.40 \\
\hline El-Minia & $28.05^{\circ}$ & $30.44^{\circ}$ & 40.00 \\
\hline \multicolumn{4}{|c|}{ Upper Egypt } \\
\hline Assuit & $27.11^{\circ}$ & $31.06^{\circ}$ & 71.00 \\
\hline Sohag & $26.36^{\circ}$ & $31.38^{\circ}$ & 68.70 \\
\hline Qena & $26.10^{\circ}$ & $32.43^{\circ}$ & 72.60 \\
\hline Aswan & $24.02^{\circ}$ & $32.53^{\circ}$ & 108.30 \\
\hline
\end{tabular}

Source: own elaboration.
, Cairo, Beni Sweif and Fayom governorates); (5) Middle Egypt (Sohag, Qena, Assuit and Minia governorates) and (6) Upper Egypt region (Aswan governorate). A more recent classification was published by KHALIL et al. [2011], where CROPWAT model [FAO 1992] was used to calculate PET using 10-year weather data for 20 governorates. These zones were: (1) Alexandria and Demiatte; (2) Dakhlia and North Sinai; (3) Kafr El-Sheikh and El-Gharbia; (4) Ismailia, El-Sharkia and El-Monofia; (5) El-Kalubia, Beni Sweif and El-Minia (6) Giza, Qena, Sohag and El-Wadi El-Gedid; (7) El-Behira and El-Fayom and (8) Assuit and Aswan. The problem with this classification is it includes one governorate cultivated under rain fed (North Sinai) and another governorate cultivated using ground water (El-Wadi El-Gedid) and the soil of these two governorates is sandy in texture.

The objective of this paper was to develop agroclimatic zones in the old cultivated land of Egypt in the Nile Delta and Valley using climate normal from 1985-2014. Such zoning can facilitate better irrigation water management under water scarcity conditions. 


\section{CLIMATE DATA}

Daily climate data for the selected governorates from 1985 to 2014 were collected for each governorate. These data were solar radiation $\left(\mathrm{MJ} \cdot \mathrm{m}^{-2} \cdot \mathrm{day}^{-1}\right)$, maximum, minimum and mean air temperature $\left({ }^{\circ} \mathrm{C}\right)$, wind speed $\left(\mathrm{m} \cdot \mathrm{s}^{-1}\right)$ and dew point temperature $\left({ }^{\circ} \mathrm{C}\right)$. Monthly means were calculated for each year and then monthly values for the 30 years were calculated for each governorate.

\section{USING BISM MODEL TO CALCULATE PET}

BISm model (the basic irrigation scheduling model) SNYDER et al.[2004] was used to calculate monthly PET using the Penman-Monteith equation MONTEITH [1965] as presented in FAO Irrigation and Drainage Paper (FAO 56) by ALLEN et al. [1998]. The station latitude and elevation must be input. Thus, we obtained values for PET for 30 years for 17 governorates.

\section{STATISTICAL ANALYSIS}

Descriptive statistical analysis for the weather elements were performed to calculate the mean, which is the total value divided by the number of observation and the range, which is the difference between highest and lowest values [SENDECOR, COCHRAN 1980]. Analysis of variance was done using one factor randomize complete block design (governorates), with 30 replications (number of years). Then, the means was separated and ranked using least significant difference test $\left(L S D_{0.05}\right)$ [SENDECOR, COCHRAN 1980]. Furthermore, coefficient of determination $\left(R^{2}\right)$ between each weather element and PET was calculated to test the strength of the relationship between them [DRAPER, SMITH 1987].

\section{RESULTS AND DISCUSSION}

\section{CLIMATE NORMALS AND PET VALUES}

The climate normals and PET values for each governorate are presented in Table 2 . The results indicated that there was a gradient from North to South of Egypt for solar radiation, maximum and mean air temperature where the range between low and high value of solar radiation was $2.97 \mathrm{MJ} \cdot \mathrm{m}^{-2} \cdot \mathrm{day}^{-1}$ and it was 8.02 and $4.18^{\circ} \mathrm{C}$ for maximum and mean air temperature, respectively. KHALIL et al. [2011] indicated that the range for mean temperature was $6.2^{\circ} \mathrm{C}$ when using 10-year weather data from 1997-2006.

Regarding to minimum and dew point temperature, it is high in the Nile Delta and Middle Egypt and start to be lower from El-Minia to Aswan governorates. Wind speed is decreasing from North to South, with $0.96 \mathrm{~m} \cdot \mathrm{s}^{-1}$ difference between high and low values. KHALIL et al. [2011] indicated that the range for wind speed was $1.6 \mathrm{~m} \cdot \mathrm{s}^{-1}$ when 10-year weather data was used to calculate $P E T$. The interactive effect of these climate data on PET showed an increase in its values as we go South of Egypt.

The highest $R^{2}$ values were found between maximum air temperature and $P E T$, followed by mean air temperature, i.e. 0.91 and 0.86 , respectively. Low $R^{2}$ value was obtained between wind speed and PET. Similar results were obtained for mean temperature and wind speed by KHALIL et al. [2011] when 10-year weather data was used to calculate $P E T$.

Table 2. Climate normals and PET values for 17 governorates in Egypt

\begin{tabular}{|l|r|r|r|r|r|r|r|}
\hline Governorate & $S R A D$ & $T_{\max }$ & $T_{\min }$ & $T_{\text {mean }}$ & $W S$ & $T d$ & $P E T$ \\
\hline \multicolumn{7}{|c|}{ Nile Delta } \\
\hline Alexandria & 20.96 & 24.42 & 18.17 & 21.29 & 3.57 & 15.17 & 4.52 \\
Damietta & 19.88 & 25.73 & 17.65 & 21.69 & 3.29 & 14.65 & 4.66 \\
Kafr El-Sheik & 20.37 & 25.29 & 17.72 & 21.50 & 3.39 & 14.72 & 4.64 \\
El-Dakahlia & 19.88 & 25.73 & 17.65 & 21.69 & 3.29 & 14.65 & 4.66 \\
El-Behira & 19.89 & 29.20 & 15.40 & 22.30 & 2.72 & 12.40 & 5.26 \\
El-Gharbia & 19.65 & 29.25 & 15.35 & 22.30 & 2.68 & 12.35 & 5.18 \\
El-Minofia & 19.67 & 29.43 & 15.31 & 22.37 & 2.61 & 12.31 & 5.19 \\
El-Sharkia & 19.65 & 29.58 & 15.46 & 22.52 & 2.61 & 12.46 & 5.28 \\
El-Kalubia & 19.64 & 29.68 & 15.61 & 22.64 & 2.61 & 12.61 & 5.36 \\
\hline \multicolumn{7}{|c|}{ Middle Egypt } \\
\hline El-Giza & 19.55 & 29.69 & 15.64 & 22.66 & 2.65 & 12.64 & 5.37 \\
El-Fayom & 21.02 & 29.77 & 15.91 & 22.84 & 2.81 & 12.91 & 5.59 \\
Beni Sweif & 20.78 & 29.87 & 15.38 & 22.62 & 2.70 & 12.38 & 5.55 \\
El-Minia & 21.33 & 29.99 & 16.41 & 23.20 & 2.91 & 13.41 & 5.69 \\
\hline \multicolumn{7}{|c|}{ Upper Egypt } \\
\hline Assuit & 21.59 & 30.02 & 16.40 & 23.21 & 2.98 & 13.40 & 5.78 \\
Sohag & 22.11 & 30.36 & 16.83 & 23.59 & 2.96 & 13.83 & 5.85 \\
Qena & 21.61 & 31.18 & 17.06 & 24.12 & 2.95 & 14.06 & 5.96 \\
Aswan & 22.52 & 32.44 & 18.51 & 25.47 & 2.84 & 15.51 & 6.16 \\
\hline Mean & 20.59 & 28.92 & 16.50 & 22.71 & 2.92 & 13.50 & 5.33 \\
Range & 2.97 & 8.02 & 3.19 & 4.18 & 0.96 & 3.19 & 1.64 \\
$R^{2}$ & 0.52 & 0.91 & 0.01 & 0.86 & 0.23 & 0.01 & 1.00 \\
\hline
\end{tabular}

Explanations: $S R A D=$ solar radiation, $\mathrm{MJ} \cdot \mathrm{m}^{-2} \cdot \mathrm{day}^{-1}, T_{\max }=$ maximum air temperature, ${ }^{\circ} \mathrm{C}, T_{\min }=$ minimum air temperature, ${ }^{\circ} \mathrm{C}, T_{\text {mean }}$ $=$ mean air temperature, ${ }^{\circ} \mathrm{C}, W S=$ wind speed, $\mathrm{m} \cdot \mathrm{s}^{-1}, T d=$ dew point temperature, ${ }^{\circ} \mathrm{C}, P E T=$ potential evapotranspiration, $\mathrm{mm} \cdot \mathrm{day}^{-1}$. Source: own elaboration.

\section{ANALYSIS OF VARIANCE}

Analysis of variance indicated that both years and PET values were significantly differed (Tab. 3). The years in the analysis are an indirect indication of weather conditions and consequently it affects the values of PET. Similar results were obtained by KHALIL et al. [2010], where both years and PET was significantly differed.

Table 3. Analysis of variance for PET values of the 17 governorates

\begin{tabular}{|l|c|r|c|c|c|}
\hline Source & $\begin{array}{c}\text { Degree of } \\
\text { freedom }\end{array}$ & $\begin{array}{c}\text { Sum of } \\
\text { squares }\end{array}$ & $\begin{array}{c}\text { Mean } \\
\text { squares }\end{array}$ & $F$ value & $\begin{array}{c}\text { Proba- } \\
\text { bility }\end{array}$ \\
\hline Years & 29 & 62.693 & 2.162 & 63.943 & 0.0000 \\
\hline PET & 16 & 117.229 & 6.896 & 203.966 & 0.0000 \\
\hline Error & 464 & 16.668 & 0.034 & - & - \\
\hline Total & 508 & 196.590 & - & - & - \\
\hline
\end{tabular}

Source: own elaboration. 


\section{SEPARATION OF PET MEANS AND DETERMINATION OF AGRO-CLIMATIC ZONES}

The separation of PET means into groups revealed that 7 agro-climatic zones can be distinguished according to the $L S D_{0.05}$ test, which was equal to 0.138. Starting from North of Egypt, Alexandria by itself is the first zone, where it has the least PET value $\left(4.52 \mathrm{~mm} \cdot \mathrm{day}^{-1}\right)$. Zone (2) is composed of three governorates: Damietta, Kafr El-Sheik and El-Dakahlia, with average PET value equal to $4.69 \mathrm{~mm} \cdot \mathrm{day}^{-1}$. Two governorates exist in zone (3), i.e. El-Behira and El-Gharbia, where the average value of PET was 5.07 $\mathrm{mm} \cdot$ day $^{-1}$. El-Minofia and El-Sharkia, El-Kalubia, Giza and El-Fayom are in zone (4) with average PET value equal to $5.356 \mathrm{~mm} \cdot \mathrm{day}^{-1}$. Beni Sweif, El-Minia, Assuit and Sohag are located in zone (5), where its $P E T$ value is equal to $5.78 \mathrm{~mm} \cdot \mathrm{day}^{-1}$. Zone (6) contains one governorate, i.e. Qena with $P E T$ value equal $6.00 \mathrm{~mm} \cdot \mathrm{day}^{-1}$. Similarly, zone (7) contains one governorate, i.e. Aswan with PET value equal to $6.17 \mathrm{~mm} \cdot \mathrm{day}^{-1}$ (Tab. 4).

Table 4. Agro-climatic zones of Egypt as determined by statistical analysis

\begin{tabular}{|c|c|c|}
\hline Zone number & Governorate & $P E T, \mathrm{~mm} \cdot$ day $^{-1}$ \\
\hline 1 & Alexandria & 4.52 \\
\hline \multirow{3}{*}{2} & Demiatte & 4.70 \\
\hline & Kafr El-Sheik & 4.68 \\
\hline & El-Dakahlia & 4.70 \\
\hline \multirow{2}{*}{3} & El-Behira & 5.08 \\
\hline & El-Gharbia & 5.06 \\
\hline \multirow{5}{*}{4} & El-Monofia & 5.18 \\
\hline & El-Sharkia & 5.25 \\
\hline & El-Kalubia & 5.35 \\
\hline & Giza & 5.41 \\
\hline & El-Fayom & 5.55 \\
\hline \multirow{4}{*}{5} & Beni Sweif & 5.68 \\
\hline & El-Minia & 5.74 \\
\hline & Assuit & 5.81 \\
\hline & Sohag & 5.88 \\
\hline 6 & Qena & 6.00 \\
\hline 7 & Aswan & 6.16 \\
\hline \multirow{2}{*}{\multicolumn{2}{|c|}{$\begin{array}{l}\text { Mean } \\
L S D_{0.05}\end{array}$}} & 5.33 \\
\hline & & 0.146 \\
\hline
\end{tabular}

Source: own elaboration.

The results in the Table 4 revealed that the governorates of Middle Egypt were separated and joined Nile Delta governorates and Upper Egypt governorates, where El-Giza and Fayom joined Nile Delta governorates and Beni Sweif and El-Minia joined Upper Egypt governorates (Fig. 2).

\section{CONCLUSION}

The presented methodology in this paper classified the old land of heavy soils in Egypt into 7 agro-climatic zones. Such zoning will increase the ability of the Egyptian policy makers to prepare the appropriate developmental policies, where the availability of proper information on each zone can help them. Furthermore, this methodology is easy to be implemented in the developing countries, where low technology is available.

\section{REFERENCES}

ABOU ZEID K. 2002. Egypt and the world water goals. Egypt statement [World Summit for Sustainable Development]. [26 August-4 September 2002 Johannesburg. South Africa].

Allen R.G., Pereira L.S., Raes D., Smith M. 1989. Crop evapotranspiration: guideline for computing crop water requirements. FAO Irrigation and Drainage Paper. No. 56. Rome pp. 300.

DoOREnBOS J., KASSAM A. 1979. Yield response to water. FAO Irrigation and Drainage Paper. No. 33. Rome pp. 176.

DRAPER N.R., Smith H. 1987. Applied regression analysis. New York. John Wiley and Sons. Inc. ISBN 9780471170822 pp. 736.

Eid H.M., El-Marsafawy S.M., Ouda S.A. 2006. Assessing the impact of climate on crop water needs in Egypt: the CROPWAT analysis of three districts in Egypt. CEEPA Discussion Papers. No. 29 pp. 35.

EL-BAGOURI I.H.M. 2008. Management of productive lands of Egypt. A presentation [IGBP. Regional Workshop, MENA]. [20-21 November 2008, Cairo, Egypt].

FAO 1983. Land evaluation of rain-fed agriculture. Soil Bulletin. No. 52. Rome pp. 237. 
FAO 1992. CROPWAT, a computer program for irrigation planning and management by M. Smith. FAO Irrigation and Drainage Paper. No. 26. Rome pp. 126.

Gardner F.P., Pearce R.B., Mitchell R.L. 1985. Physiology of crop plants. Ames. Iowa State University Press. ISBN 081381376X pp. 327.

Khalil F., Ouda S.A., OSMAn N., Khamis E. 2011. Determination of agro-climatic zones in Egypt using a robust statistical procedure. Proceeding of the $15^{\text {th }}$ International Conference on Water Technology. Alexandria, Egypt. 30 May-2 June p. 65-71.

Medany M. 2007. Water requirement for crops in Egypt. Giza. Agricultural Research Center. Egypt. Central Laboratory of Agricultural Climate pp. 245.
MONTEITH J.L. 1965. Evaporation and environment. In: Symposium of the Society for Experimental Biology: The state and movement of water in living organisms. Ed. G.E. Fogg. Vol. 19. Academic Press Inc., NY p. 205-234.

SNEDECOR G.W., COCHRAN W.G. 1980. Statistical methods. $7^{\text {th }}$ ed. Ames. Iowa State University Press. ISBN 0813815606 pp. 507.

SNYDER R.L., ORANG M., BALI K., ECHING S. 2004. Basic irrigation scheduling BISm [online]. [Access 7.05.2016]. Available at: http://www.waterplan.water. ca.gov/landwateruse/wateruse/Ag/CUP/Californi/ Climate_Data_010804.xls

\section{Tahany NORELDIN, Samiha OUDA, Alia AMER}

\section{Wyznaczanie agroklimatycznej strefowości w Egipcie w celu poprawy gospodarki wodnej}

\section{STRESZCZENIE}

W pracy wyodrębniono strefy agroklimatyczne na uprawianych od dawna ziemiach doliny i delty Nilu w Egipcie na podstawie danych klimatycznych $\mathrm{z}$ lat 1985-2011 w celu usprawnienia zarządzania nawodnieniami w warunkach deficytu wody. Zebrano miesięczne dane klimatyczne z 30 lat z 17 gubernatorstw o charakterze rolniczym w Egipcie i obliczono wartości średnie roczne analizowanych parametrów oraz średnie z 30 lat. Użyto modelu BISm do obliczenia średnich rocznych wartości ewapotranspiracji potencjalnej $(E T P)$ i średniej wartości ETP z 30 lat dla każdego gubernatorstwa. Przeprowadzono jednoczynnikową analizę wariancji losowych bloków z liczbą lat jako powtórzeniem. Ponadto obliczono średnią, zakres i współczynnik determinacji $R^{2}$ dla ustalenia siły zależności pomiędzy ETP i czynnikami klimatycznymi. Średnie wartości ETP obliczono dla każdego gubernatorstwa i uporządkowano rosnąco, stosując test najmniejszej istotnej różnicy $\left(L S D_{0.05}\right)$. Wyodrębnione strefy to: 1) Aleksandria, 2) Demiatte, Kafr El-Sheikh i Dakhlia, 3) El-Behira i El-Gharbia, 4) El-Minofia, El-Sharkia, El-Kalubia, Giza i El-Fayom, 5) Beni Sweif, El-Minia, Assuit i Sohag, 6) Qena i 7) Assuan. Podział na te strefy przyczyni się do zwiększenia zdolności czynników decyzyjnych w Egipcie do prowadzenia odpowiedniej gospodarki wodnej i polityki rozwoju dzięki dostępności do właściwej informacji o każdej strefie w celu efektywnego użytkowania ograniczonych zasobów wodnych.

Slowa kluczowe: ewapotranspiracja potencjalna, gubernatorstwo, równanie Penmana-Monteitha, trzydziestoletnie dane klimatyczne, wydajne użtkowanie wody 